THE LOGIC OF EVANGELISM William J. Abraham In this book William J. Abraham addresses the dearth of modern theology on the topic of evangelism. In contrast both to the traditional focus on proclamation and to the more recent emphasis on church growth, Abraham argues that evangelism should be construed as primary initiation into the kingdom of God.

Paper, \$12.95

\section{THEOLOGICAL}

DICTIONARY OF THE OLD

TESTAMENT, Volume VI

Edited by G. Johannes Botterweck and Helmer Ringgren

Translated by David E. Green

Volume 6 of this major, multivolume reference work contains fifty-five comprehensive articles, ranging from yôbel, "jubilee," to yätar, "be abundant; remnant." Thirty-three contributors from nine countries in North America and Europe comprise an interconfessional representation of the best in current biblical and theological scholarship.

Cloth, $\$ 35.95$

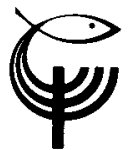

OUR FATHER ABRAHAM

Jewish Roots of the

Christian Faith

Marvin R. Wilson

Delineating the link between Judaism and Christianity, this volume calls Christians to reexamine their Hebrew roots so as to effect a more authentically biblical lifestyle. While the book is biblical, historical, and cultural in nature, the writing is personal and passionate, reflecting Wilson's own spiritual pilgrimage and his extensive dialogue with Jews.

Paper, \$15.95

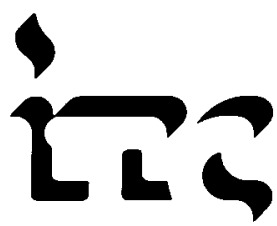

INTERNATIONAL

THEOLOGICAL

COMMENTARY

Fredrick Carlson Holmgren and George A. F. Knight, Editors HOSEA: Grace Abounding H. D. Beeby

Stressing that the true context of Hosea is much wider than the eighth century B.C., Beeby argues that the message of Hosea is relevant to all who today struggle with questions of gospel and culture, contextualization, idolatry, church and state, and inter-faith dialogue.

Paper, $\$ 12.95$

MICAH: Justice and Loyalty Juan I. Alfaro, O.S.B.

Alfaro examines the prophecies of Micah as they address the internal and external crises that faced Judah in the eighth century B.C., and interprets their fulfillment not as dead literary or historical events but as living and timeless challenges to heed even today their message of change and conversion.

Paper, $\$ 7.95$

\section{READING THE NEW \\ TESTAMENT \\ Patrick Grant}

"Patrick Grant brings to his reading of the New Testament a mind and a sensibility trained, to an exceptional degree, in both literature and philosophical theology. . . He is capable of organizing the complex resources of his mind in the service of a powerful idea: that innocent suffering, so far from refuting Christianity, is in fact central to any real understanding of it." - A. D. NUTTALL
I BELIEVE IN THE

HOLY SPIRIT

Revised Edition

Michael Green

In this revised edition of his popular book, Michael Green traces the doctrine of the Holy Spirit through the Old and New Testaments and then addresses the particular issues that engage so much attention today - especially the relation of the church to the Spirit's work and the baptism, gifts, and fullness of the Spirit.

Paper, $\$ 12.95$

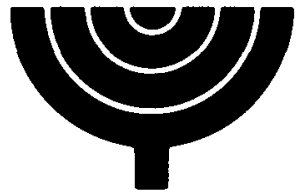

THE NEW INTERNATIONAL COMMENTARY ON THE

OLD TESTAMENT

R. K. Harrison, General Editor THE BOOKS OF NAHUM, HABAKKUK, AND ZEPHANIAH

\section{O. Palmer Robertson}

In this volume, the latest addition to the NICOT series, Robertson combines the insights of biblical theology with an awareness of the age in which we live. The result is a relevant confrontation with the ancient call to repentance and faith - a confrontation greatly needed in today's world.

Cloth, \$28.95

\section{ECONOMICS TODAY}

\section{A Christian Perspective}

Donald A. Hay

Writing as both a Christian and an academic economist, Donald Hay provides biblically based principles for economic life and a critique of economic methodology in light of a Christian understanding of truth.

Paper, $\$ 17.95$

\title{
SPRING/SUMMER 1989
}


ACADEMIC BOOKS

LIBERATING NEWS

A Theology of Contextual Evangelization

Orlando E. Costas

This book approaches the topic of contextual evangelization from the standpoint of "the poor, the powerless, and the oppressed." Costas's creative, sound blend of evangelical commitment and enlightened social thinking recommends this book to well-informed laypeople as well as to pastors, theologians, and scholars.

Paper, \$12.95

\section{SPEAKING FROM}

THE DEPTHS

Alfred North Whitehead's

Hermeneutical Metaphysics

of Propositions, Experience, Symbolism, Language,

and Religion

Stephen T. Franklin

This monumental work, which breaks new ground in exploring some of the hermeneutical implications of Whitehead's philosophy, arises out of the author's quest to find a way of explaining how human language can speak of God.

Paper, \$27.50s

\section{THE ACTS OF THE}

APOSTLES

The Greek Text with

Introduction and Commentary Third Revised and Enlarged Edition F. F. Bruce

In making this extensive revision of his major work on the Greek text of Acts, first published in 1951, Bruce has taken into account the tremendous volume of scholarly work and the advances in linguistics and historical knowledge during the last four decades.

Cloth, $\$ 39.95$
ALTERED LANDSCAPES

Christianity in America 1935-1985

Edited by David W. Lotz with Donald W. Shriver, Ir., and John $F$. Wilson

In this in-depth exploration of the most significant developments in American Christianity from 1935 to 1985 , twenty-one noted scholars provide a coherent description and interpretation of what Martin E. Marty, in the introduction, calls the "altered landscapes" of religion in America over the last fifty years. Cloth, \$27.95; Paper, \$17.95

\section{JESUS IS THE CHRIST}

Studies in the Theology of John Leon Morris

In response to questions and comments from his seminary students, Morris has written this book solely on the theology of John: his work offers new and sometimes surprising insights into this pivotal New Testament book.

Paper, \$12.95

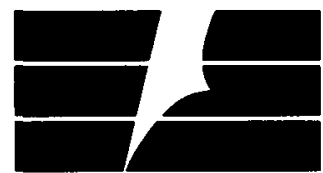

THE NEW CENTURY BIBLE COMMENTARY

Ronald E. Clements and Matthew Black, Editors ECCLESIASTES

\section{R. N. Whybray}

Offering a clear exposition of the text, Whybray demonstrates that although Ecclesiastes in many ways is characteristic of the time when it was written the Hellenistic period - the book still stands firmly within the tradition of Old Testament wisdom literature.

Paper, \$13.95
THE LIVING PSALMS

Claus Westermann

"This selection of Psalms is a pleasure to have. . . Lay people will appreciate its directness and lack of jargon. Students will benefit ... from expert economical orientation on the main types of Psalms, and fellow specialists will enjoy the technique of a master at work."

-GRAEME AULD

Cloth, \$27.95; Paper, \$17.95

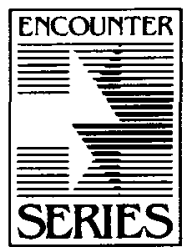

THE ENCOUNTER SERIES

Richard John Neuhaus,

General Editor

Volume 11: LAW AND THE ORDERING OF OUR LFE

\section{TOGETHER}

Contributors are Bruce $C$.

Hafen, Thomas L. Shaffer,

Susan S. Silbey, Richard Stith, and Edwin $A$. Rodriguez

Paper, \$13.95

Volume 12: REINHOLD NIEBUHR TODAY

Contributors are Richard Wightman Fox, Michael J. Sandel, Ralph McInerny, and Paul T. Stallsworth

Paper, $\$ 10.95$

Prices subject to change without notice.

For more information on these and other Eerdmans titles, write for a copy of our most recent Eerdmans Academic Catalog. Examination copies of most titles are available to qualified professors.

At your bookstore, or call 1-800-633-9326 FAX 616-459-6540 


\section{FALL/WINTER BOOKS}

\section{THE TEXT OF THE} NEW TESTAMENT An Introduction to the Critical Editions and to the Theory and Practice of Modern Textual Criticism Second Edition

Revised and Enlarged

Kurt Aland and

Barbara Aland

Translated by Emoll F. Rhodes

This extensive revision of the

Alands' definitive introduc-

tion to New Testament textual studies reflects significant developments in the field since completion of the first edition in 1980 .

Cloth, $\$ 32.50$

\section{TWO HUNDRED YEARS OF THEOLOGY}

Report of a Personal Journey Hendrikus Berkhof

"Through lucid and readable analysis of major thinkers and movements, Berkhof helps the reader re-think the nature and task of theology in any age. The book is at once a fine history and original theology."

Cloth, $\$ 29 . \overline{95}$ JOHN B. COBB, JR

\section{AN EMBER STILL}

GLOWING

Humankind as the

Image of God

Harry R. Boer

A critique of basic emphases in traditional Reformed theology and the development of the image of God concept as a corrective and reinvigorating force to perpetuate the vitality of the tradition.

Paper, $\$ 14.95$

\section{GOD'S NEW COVENANT A New Testament \\ Translation \\ Translated by \\ Heinz W. Cassirer \\ "Impressive dignity. ..."}

"A tour de force ... [It] combines scrupulous scholarship, expert knowledge of the original Greek, and the approach of a fresh and lively mind to the text of the New Testament." Cloth, $\$ 19.95$ -PAUL ELLINGWORTH

\section{BODY, SOUL, AND LIFE} EVERLASTING

\section{Biblical Anthropology}

and the Monism-

Dualism Debate

John W. Cooper

"Careful, thoughtful, and thorough.... Provides a much needed antidote to the facile endorsements of mind-body monism so characteristic of contemporary theology and philosophy."

Paper, $\$ 16.95$ -ALVIN PLANTINGA

\section{HOW DOES AMERICA} HEAR THE GOSPEL?

William A. Dyrness

"This is a profound study of how the Gospel relates to the North American context. Dyrness combines cross-cultural sensitivities with theological astuteness and a solid grasp of American experience and traditions." Paper, $\$ 11.95$ -RICHARD MOUW

\section{PAULINE THEOLOGY} Ministry and Society E. Earle Ellis

"Earle Ellis is a distinguished New Testament specialist who stands out as a scholar unafraid to draw out implications of biblical thought for the church

today." -CLARK H. PINNOCK Paper, $\$ 14.95$

\section{THE ACTUALITY OF} ATONEMENT

A Study of Metaphor,

Rationality, and the

Christian Tradition

Colin E. Gunton

Gunton attempts to recover the doctrine of atonement, a cur- rently neglected dimension of Christian teaching by presenting a new approach through the philosophy of language. Cloth, $\$ 24.95$

\section{WHY NARRATIVE?}

Readings in Narrative Theology

Stanley Hauerwas and

L. Gregory Jones, editors "Absorbing reading; splendid reference; ideal as a theology course reader."

-IAMES MCCLENDON, JR. Cloth, \$29.95; Paper, \$19.95

\section{SAVED BY GRACE}

Anthony A. Hoekema The crowning achievement of a lifetime of thought and reflection, Saved by Grace is a comprehensive, dynamic, and eminently practical presentation of the biblical teaching on salvation.

Cloth, \$22.95

\section{ARCHBISHOP}

CRANMER'S IMMORTAL BEQUEST

The Book of Common

Prayer of the Church of England: An

Evangelistic Liturgy Samuel Leuenberger

Focusing on The Book of

Common Prayer of 1662 Leuenberger interweaves historical events and theological themes to show how revivalism and puritanism shaped the development of the Prayer Book.

Paper, $\$ 29.95$

\section{DIAKONIA IN THE} CLASSICAL REFORMED TRADITION AND TODAY

\section{Elsie Anne McKee}

McKee studies the Calvinist churches' teaching and practice of the service or diaconal minis. try of Christians, focusing especially on its development in the Protestant Reformation and its redevelopment in the late twentieth century.

Paper, $\$ 12.95$ 


\section{FROM EERDMANS}

\section{CONFESSOR BETWEEN}

EAST AND WEST

A Portrait of Ukrainian

Cardinal Josyf Slipyj

Jaroslav Pelikan

This major work by eminent historian Jaroslav Pelikan tells the absorbing story of the life of Cardinal Slipyj, the Ukrainian churchman whose long and tumultuous life embodied the tensions between Eastern and Western Christendom.

Cloth, $\$ 29.95$

\section{DIAKONIA}

Mutual Helping with Justice and Compassion

Jaap van Klinken

"A thoughtful, wide ranging and critically constructive study of the church's diakonia and diaconate in the context of contemporary needs and practice."

-GEOFFREY W. BROMILEY Paper, $\$ 14.95$

\section{TERMINAL CHOICES}

Euthanasia, Suicide, and the Right to Die

Robert $N$. Wennber

"A superb book on the utterly sensitive issues of euthanasia and suicide.... It is judicious, penetrating, comprehensive, Christianly profound and lucid, and wonderfully readable."

Paper, $\$ 13.95$ -LEWIS B. SMEDES

\section{AN UNSETTLED ARENA}

Religion and the

Bill of Rights

Ronald C. White, Jr.

and Albright $G$.

Zimmerman, editors

"An arresting set of essays that center on the First Amendment religion clauses but range very widely to explore church-state issues in our society and beyond."

Paper, $\$ 14.95$
THE STRUGGLE FOR AMERICA'S SOUL Evangelicals, Liberals, and Secularism

Robert Wuthnow

"Robert Wuthnow is one of the most astute and judicious observers of the contemporary religious and cultural scene. This is his most accessible book. I recommend it." -GEORGE MARSDEN

Cloth, \$22.95; Paper, \$16.95

$$
\text { (A)IIITIR\}SRH }
$$

THE NEW CENTUR $\$ BIBLE COMMENTARY

Ronald Clements and

Matthew Black, editors

ROMANS

(Second Edition)

Matthew Black

Paper, \$13.95

\section{THE NEW}

INTERNATIONAL

COMMENTARY ON THE

OLD TESTAMENT

R. K. Harrison, editor

\section{THE BOOK OF GENESIS}

Victor P. Hamilton

Cloth, $\$ 34.95$

\section{INTERNATIONAL}

THEOLOGICAL

COMMENTARY

Fredrick Holmgren and George A. F. Knight, editors

ISAIAH 1-39

The Lord is Savior

Faith in National Crisis

S. H. Widyapranawa

Paper, \$14.95

At your bookstore, or call 1-800-633-932

In Michigan, call collect 616-459-4591

FAX 616-459-6540

\section{TMNDALE NEW \\ TESTAMENT COMMENTARIES}

Leon Morris, nevision editor EPHESIANS (Revised)

Francis Foulkes

Paper, $\$ 7.95$

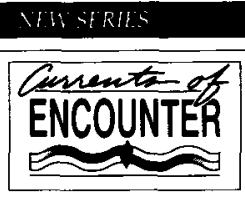

\section{CURRENTS OF}

\section{ENCOUNTER}

Studies on the contact between Christianity and other religions, beliefs, and cultures.

\section{DIALOGUE AND} SYNCRETISM

An Interdisciplinary Approach

J. D. Gort, H. M. Vroom,

R. Fernhout, and

A. Wessels, editors

Paper, $\$ 17.95$

\section{RELIGIONS AND}

THE TRUTH

Philosophical Reflections and Perspectives Hendrik M. Vroom

Paper, $\$ 23.95$

Prices subject to change without notice

For more information on these and other Eerdmans titles, write for a copy of our most recent Academic Catalog. Examination copies of most titles are available to qualified professors. 


\section{SPRING/SUMMER BOOKS}

\section{EXEGETICAL DICTIONARY OF THE NEW TESTAMENT \\ Volume 1 \\ Edited by Horst Balz and Gerhard Schneider}

The first volume of a projected three-volume set which offers a complete lexicon for the English-speaking reader of New Testament Greek as well as a superb guide to the usage of every New Testament word and to modern New Testament scholarship.

Cloth, $\$ 39.95$

\section{RETURN TO REASON}

A Critique of Enlightenment Evidentialism and a Defense of Reason and Belief in God Kelly James Clark

A clear, cogent account of the recent work on the rationality of religious belief, this book helps bridge the existing gap between technical philosopher and educated layperson.

Paper, \$10.95

\section{THE FUNDAMENTALIST \\ PHENOMENON}

\section{A View from Within;}

\section{A Response from Without}

\section{Edited by Norman I. Cohen}

The work of some of today's leading academicians, theologians, and thinkers, this book assesses the nature of fundamentalism and its impact on our social, political, and religious life. Contributors include Jaroslav Pelikan, George M. Marsden, Clark H. Pinnock James Davison Hunter, Richard John Neuhaus, James M. Dunn, Leon Wieseltier, and Donald W. Shriver, Jr.

Paper, $\$ 14.95$

\section{THE TECHNOLOGICAL BLUFF}

\section{Jacques Ellul}

A masterpiece of contemporary critical analysis, this book presents a penetrating critique of modern technology which cuts across several areas - sociology, social ethics, economics, history, political science, and philosophy of science.

Cloth, $\$ 24.95$

\section{REVOLUTION WITHIN THE REVOLUTION}

The First Amendment in Historical Context, 1612-1789 William R. Estep

Foreword by Bill Moyers

Distinguished historian William Estep offers in this book a lively account of the persons and events that influenced the shaping of the First Amendment.

Paper, $\$ 14.95$

\section{THE FABRIC OF THIS WORLD}

Inquiries into Calling, Career Choice, and the Design of Human Work

Lee Hardy

Thoroughly researched, historically grounded, philosophically and theologically informed, this book makes a unique contribution to the evangelical literature on work and career choice. Paper, $\$ 12.95$

\section{THE LORD'S PRAYER}

\section{Jan Milič Lochman}

This exposition by Lochman of the Lord's Prayer is thoughtful and heartfelt, full of historical and theological insights, and abounding in contemporary application.

Paper, $\$ 12.95$

\section{METAPHYSICS AND THE IDEA OF GOD \\ Wolfhart Pannenberg}

Reflecting the pervasively historical orientation of much of Pannenberg's earlier work, this book offers a superb and succinct introduction to the crisscrossings of theology and metaphysics over the last two thousand years.

Cloth, $\$ 21.95$

\section{WHY?}

\section{On Suffering, Guilt, and God \\ A. van de Beek}

In this book A. van de Beek grapples honestly with the mystery of suffering and evil. His writing reveals a pastoral heart keenly aware of the profound evil and suffering in our world today, and he considers these perplexities via a fresh, different approach.

Paper, $\$ 19.95$ 


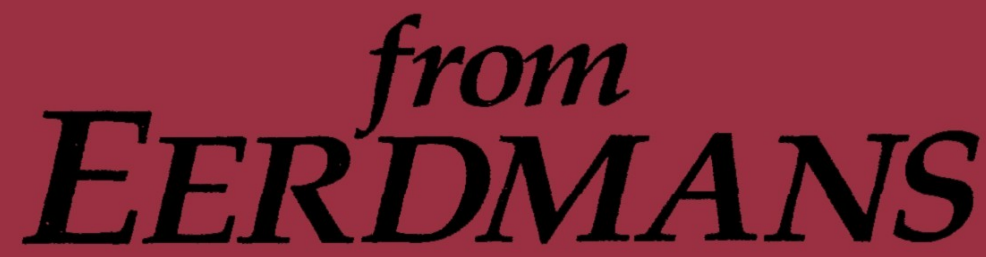

\section{IMAGES OF JESUS}

How Jesus Has Been Portrayed and Perceived in Other Cultures

Anton Wessels

A study on the variety of ways Jesus has been perceived and portrayed in different times and places throughout history.

Compelling reading for both academic and general readers

Paper, $\$ 12.95$
GOD'S PEOPLE IN GOD'S LAND

Family, Land, and Property

in the Old Testament

Christopher J. H. Wright

This unique survey examines socineconomic life in Old Testament Israel from an ethical perspective by looking at how the economic facts of Israel's social structure were related to the people's religious beliefs.

Paper, $\$ 16.95$

\section{COMMENTARY SERIES}

\section{THE NEW INTERNATIONAL GREEK} TESTAMENT COMMENTARY

W. Ward Gasque and I. Howard Marshall, editors

\section{COMMENTARY ON $1 \& 2$ THESSALONIANS \\ Charles A. Wanamaker \\ Cloth, $\$ 29.95$}

\section{THE NEW INTERNATIONAL} COMMENTARY ON THE NEW TESTAMENT

F. $E$. Bruce, editor

THE FIRST EPISTLE OF PETER

\section{Peter H. Davids}

Cloth, \$24.95

\section{THE EPISTLE TO THE HEBREWS Revised Edition \\ F. F. Bruce \\ Cloth, \$27.95}

\section{INTERNATIONAL THEOLOGICAL} COMMENTARY

Fredrick Holmgren and

G.A.F. Knight, editors

\section{JUDGES}

At Risk in the Promised Land

E. John Hamlin

Paper, $\$ 12.95$

\section{TYNDALE NEW TESTAMENT \\ COMMENTARIES \\ Leon Morris, editor}

\section{MARK \\ Revised Edition \\ R. Alan Cole \\ Paper, \$8.95 \\ GALATIANS \\ Revised Edition \\ R. Alan Cole \\ Paper, $\$ 6.95$}

Prices subject to change without notice.

For more information on these and other Eerdmans titles, write to Eerdmans Textbook Department for a copy of our most recent Academic Catalog.
At your bookstone, or call 800-633-9326 In Michigan, call collect 616-459-9591 FAX 616-459-6540

$025 \mathrm{~J}$

WM. B. EERDMANS publishing Co. 255 JEFFERSON AVE. S.E. / GRAND RAPIDS, MICH. 49503 


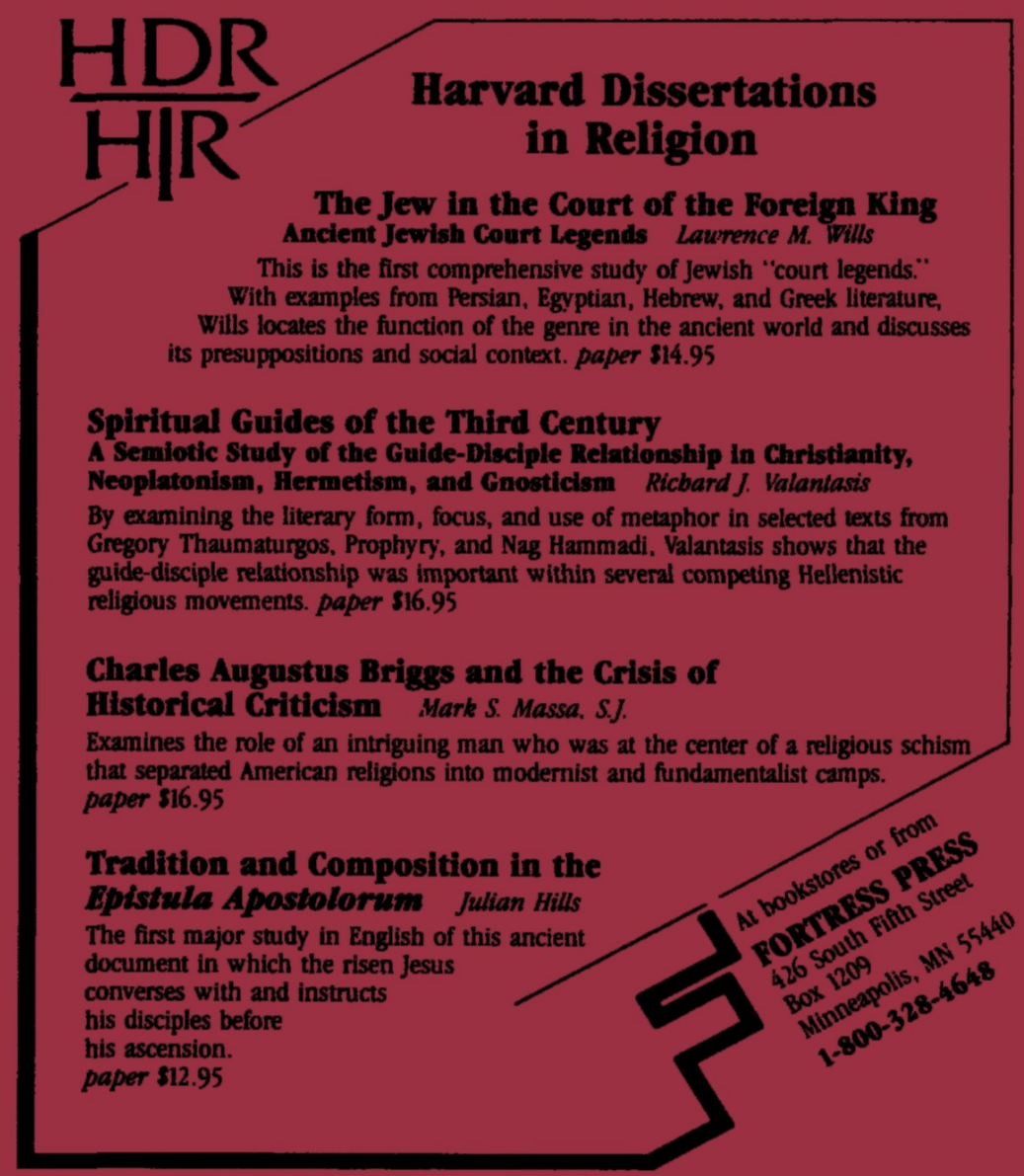

